\title{
Modern Greatness of Soul in Hume AND SMITH
}

\author{
ANDREW J. CORSA \\ Kutztown University
}

I contend that Adam Smith and David Hume offer re-interpretations of Aristotle's notion of greatness of soul, focusing on the kind of magnanimity Aristotle attributes to Socrates. Someone with Socratic magnanimity is worthy of honor, responds moderately to fortune, and is virtuous-just and benevolent. Recent theorists err in claiming that magnanimity is less important to Hume's account of human excellence than benevolence. In fact, benevolence is a necessary ingredient for the best sort of greatness. Smith's "Letter to Strahan" attributes this greatness to Hume. It encourages us to admire Hume as an exemplar of human excellence, to seek Hume's virtues for ourselves, and to approve of the "love of literary fame" which Hume calls his "ruling passion."

$\mathrm{D}$ AVID Hume and Adam Smith, each in his own way, offer re-interpretations of the kind of greatness of soul, or magnanimity, that Aristotle attributes to Socrates. While each theorist approaches this kind of greatness differently, there are common threads between their accounts. Each philosopher credits Socrates with magnanimity not entirely unlike that of heroic warriors.

Unlike some heroic warriors, those who possess Socratic magnanimity also have three key traits recognized by Aristotle, Hume, and Smith. Those with Socratic magnanimity have a distinctive-often tranquil but always moderate-response to fortune. They are distinctly concerned not with claiming honor so much as being worthy and deserving of it. And they are virtuous, possessing justice and benevolence. While Hume and Smith offer re-interpretations that differ from Aristotle's view of how these traits are to be understood, these three core traits are recognized by all three philosophers.

I particularly focus on Hume's account of what he calls "greatness of mind," the term he employs instead of "greatness of soul." Recent theorists such as Marie A. Martin suggest that, in Hume's account of human excellence, the virtues encompassed by greatness of mind have less merit or weight than those associated with 
benevolence (I992: 389). ${ }^{\text {I }}$ They rightly acknowledge that, for Hume, the virtues of greatness of mind, "when not regulated by benevolence, are fit only to make a tyrant or a public robber" $\left(\mathrm{T}_{3 \cdot 3 \cdot 3 \cdot 3 / S B N ~ 604}\right)$. Nonetheless, I argue that greatness of mind has equal merit as benevolence, in large part because of the way the best sort of greatness - that associated with Socratic magnanimity-relates to the three traits, above.

In the first half of my paper, I trace the idea of Socratic magnanimity from Aristotle to the re-interpretations offered by Hume and Smith. I focus on the three traits and on the importance of benevolence, while acknowledging the differences between philosophical interpretations.

Hume, Smith, and Aristotle offer three clearly distinct accounts of greatness. Yet Hume and Smith both offer similar answers to a question Aristotle poses in his Posterior Analytics. Aristotle asks if Socrates possesses the same kind of magnanimity that is possessed by Homeric warriors such as Achilles and Ajax. We can take Hume and Smith to claim-if indirectly-that Socratic magnanimity is both different and superior. Only Socratic magnanimity includes benevolence as a necessary ingredient, and so only it is worthy of the highest praise. In ancient times, the courage of warriors such as Achilles was most admired; in modern times we admire Socratic benevolence instead. Hume and Smith acknowledge their debt to ancient conceptions of greatness, but offer improved modern approaches.

In the second half of my paper, I turn to Adam Smith's "Letter from Adam Smith, L.L.D to William Strahan, ESQ.,” arguing that it attributes Socratic magnanimity and greatness of mind to David Hume. Smith's letter, published together with Hume's short autobiography, "My Own Life” in I777, shortly after Hume's death, serves as an obituary for Hume, and paints him as an exemplar of modern greatness of soul.

Eric Schliesser and Ryan Patrick Hanley both touch briefly on the role of magnanimity in Smith's letter, and relate it to Aristotle's concept of greatness of soul (Schliesser 2003: 338, 345-346, 350-35 I, n. 83; Hanley 2002a: 682-683). ${ }^{2}$ But they do not offer in-depth discussions of the relation between Hume's magnanimity and that of heroic warriors. It is necessary to recognize that, for Hume and Smith, there are two distinct kinds of magnanimity, warrior and Socratic, and Smith attributes only Socratic magnanimity, which is worthy of the greatest praise, to Hume.

By describing Hume as a modern great-souled man, Smith attempts to encour-

I. While Martin makes this point the most directly, Ryan Patrick Hanley also suggests that the courage Hume discusses in his "An Historical Essay on Chivalry and Modern Honour," which is directly related to his later discussions of greatness of mind, is presented in a less favorable light than "the more fitting virtues of humanity" (Hanley 2007: 302).

2. Also, more generally, see the references to ancient philosophy in "Chapter 5: Magnanimity or Classical Virtue" in Hanley (2009). 
age us to emulate Hume, ${ }^{3}$ and to seek out the virtues Hume possessed. Additionally, Smith leads us to see Hume's love of fame as a virtue 4 inasmuch as a love of fame plays a positive role in beneficent, magnanimous individuals. These are Smith's normative purposes in describing Hume as magnanimous, and they help us to better understand Smith's moral theory as well as how Hume's theory relates to it.

\section{I.I. Aristotle's Greatness of Soul}

In this section, I describe Aristotle's account of those who possess Socratic magnanimity and share three traits: a moderate response to fortune, a worthiness of honor, and virtues of justice and benevolence. In later sections, I argue that Hume and later Smith clearly distinguish Socrates's magnanimity from that of heroic warriors, and seek to praise only Socratic magnanimity, which alone has benevolence as a key ingredient.

I will not focus on the characteristics of greatness that Aristotle, Hume, and Smith do not attribute to Socrates, or on the ways in which Socrates does not fit their accounts. 5 My focus is entirely on providing a positive account of Socratic magnanimity, and on tracing the idea as it changes in its progression from Aristotle to Smith.

The key passage to consider, on its own and in relation to Hume and Smith, is Aristotle's brief discussion of greatness in Posterior Analytics:

If we were to seek what greatness of soul is we should inquire, in the case of some great-souled men we know, what one thing they all have as such. E.G. if Alcibiades is great-souled, or Achilles and Ajax, what one thing do they all have? Intolerance of insults: for one made war, one waxed wroth, and the other killed himself. Again, in the case of others, e.g. Lysander or Socrates. Well, if here it is being indifferent to good and bad fortune, I take these two things and inquire what both indifference to fortune and not brooking dishonor have that is the same. And if there is nothing, then there will be two sorts of greatness of soul. $(97 \mathrm{~b} \text { I } 6-25)^{6}$

3. Hanley implies, in a different context and by different means, that Smith's letter is designed to lead us to wish to emulate Hume (Hanley 2002a: 66I-662, 682-683). I focus on how, by attributing magnanimity to Hume, Smith can even better accomplish this goal.

4. Schliesser implies, in a different context, that Smith's letter is meant to defend and justify Hume's love of fame (Schliesser 2003: 335, 342-343).

5. For an excellent discussion of Aristotle's greatness of soul and how it does and does not relate to Socrates, see Howland (2002).

6. Jacob Howland's translation (2002: 33). Howland's translation is a "slightly modified" version of Jonathan Barnes' translation (Barnes I975). 
Does Socrates possess a different kind of greatness of soul from that of warriors such as Alcibiades, Achilles, and Ajax? Here, Aristotle leaves this question open. Nonetheless, warrior magnanimity is tied to "intolerance of insults," while Socratic magnanimity is tied to "indifference to good and bad fortune."

Jacob Howland acknowledges that Aristotle's discussion of greatness in Book 4.3 of Nicomachean Ethics (hereafter EN) expands on Socratic "indifference" (Howland 2002: 37). According to Aristotle, the great-souled man is "moderately disposed in relation to wealth, political power, and any kind of good or bad fortune ... neither . . . overly-pleased at good fortune, nor overly-distressed at bad" (EN II24aI4-I8, I49). The great-souled individual is not completely indifferent to fortune; rather, he is moderately disposed to it, and does not react overly strongly to good or bad luck. Aristotle also claims that a magnanimous individual overlooks past wrongs, and does not take seriously, nor complain about, his small problems (EN I I $25 \mathrm{a}_{4}-\mathrm{I}$ I, I 5 I).

Like Socrates, the great-souled individual must also be concerned with acquiring virtue. According to Aristotle, the magnanimous individual is worthy of the greatest honor (EN II 23 b20-24, I48-I49), and to be worthy he must be truly virtuous in every respect:

Greatness in respect of each of the excellences would seem to belong to the great-souled person. . . . He would not be worthy of honour either, if he were bad; for honour is a prize of excellence, and it is meted out to the good. Greatness of soul, then, seems to be a sort of adornment, as it were, of the excellences; for it augments them, and does not occur without them.

(EN I I 23b30-I I 24a 2, I 49)

The great-souled person possesses "each of the excellences," and could not be magnanimous "without them." Magnanimity is the finishing crown, or adornment, of virtue. As Howland points out, the word translated as "adornment" is kosmos, a “decorous arrangement, [or] 'ordered whole' that is also an 'ornament" (Howland 2002: 39). José Benardete recognizes that magnanimity has an aesthetic side; it adds beauty or "lustre" to the other virtues, and the magnanimous person "dazzles" (2013: 29, 45-46).7 Thomas Aquinas, interpreting Aristotle's passage, writes:

Every virtue ... has its own beauty or adornment which is peculiar to it. But further lustre is added by the very greatness of a virtuous deed because of magnanimity, which in Aristotle's words makes all virtues greater. (ST II-II, Q. I 29, Art. 4, ad. 3, I I3)

7. Benardete does not emphasize the aesthetic in the pages cited, but has emphasized it in discussions I shared with him. 
Aristotle would agree that Socrates possesses this kind of dazzling virtue. ${ }^{8}$ We know that Socrates bears good (and bad) fortune well, and, in Aristotle's discussion of greatness, he seems to imply that Socrates's virtuous magnanimity makes this possible: "Without excellence it is not easy to bear in a fitting way what good fortune brings" (EN I I 24a30-3 I, I 50).

In addition to virtue, magnanimity has to do with honor (EN II23b20-24, I48-I49). Hanley notes that Aristotle's account of true magnanimity has little to do with claiming honor and much to do with deserving it (Hanley 2002b: 5). According to Aristotle, the great-souled individual "thinks himself, and is, worthy of great things" (EN I $2_{23} \mathrm{~b}_{2}-3, \mathrm{I}_{4} 8$ ), and honor is "the greatest of the external goods" (EN I I 23b2o-22, I 48-I49). When the magnanimous person thinks himself worthy of great things, like honor, he must be correct-his belief warranted. Further, actually receiving the honor is of little importance. For Aristotle, a greatsouled individual is only "moderately pleased" by honors given by people of excellence, and despises honors given for small things (EN I I24a5-aI4, I 49; Hanley 2002 b: 6-7). But while honor itself is "of small consequence" (EN I I24a I 8-20, I49), it is important that the individual be worthy of honor. What others think about him is not as important as his own recognition of worthiness. Aristotle writes that the great-souled individual cares more for truth than for reputation (EN: I I 24b26-3 I, I 50-I 5 I; Hanley 2002b: I 5).

This emphasis on truth over reputation fits Socrates. Likewise, Aristotle is clear that the more virtuous an individual is, across the range of virtue, the more actually worthy or deserving he is (Hanley 2002b: 8-9). Socrates, who is most virtuous, should then be considered most worthy and magnanimous.

\section{I.2. Tracing Magnanimity from Hume to Aristotle}

In this section, I argue that Hume's conception of greatness of mind is a descendant of Aristotle's account of greatness of soul. I claim that Hume offers a reinterpretation with substantial modifications to Aristotle's theory. This is a key step toward the argument I will make in the next section that, while Hume acknowledges the debt his notion of greatness has to ancient authors, by emphasizing and specifically praising Socratic magnanimity, he affects a shift from ancient to modern times-from an emphasis on courage to an emphasis on benevolence.

While Hume does not explicitly acknowledge his debt to Aristotle on this topic, he does acknowledge the influence of Longinus and Cicero, both of whose

8. Walter Kaufmann suggests that Aristotle's conception of greatness of soul was influenced, in particular, by Plato's Apology (Kaufmann I960: I 8). While defending this point is outside the scope of this present paper, I am inclined to agree, and to think that Plato's depiction of Socrates emphasizes his greatness. 
accounts themselves owe debts to Aristotle. ${ }^{9}$ Likewise, there are substantial similarities between Hume's and Aristotle's accounts of greatness, and it is valuable to read them in comparison.

In Hume's first surviving letter, written when he was sixteen to his friend Michael Ramsey in I727, Hume describes his early idea of "Greatness \& Elevation of Soul" (Letters No. I, Iо). ${ }^{\text {Io }}$ There, he explicitly cites the influence of both Cicero and Longinus on his account of the great-souled philosopher. In his letter, Hume focuses on the great-souled individual's indifference to fortune. He writes that he has been reading Cicero and Virgil for pleasure, and that both "agree in peace of mind, in Liberty \& Independency on Fortune, \& Contempt of Riches, Power \& Glory" (Letters No. I, IO). Hume implies that he desires a "peace of Mind . . . to $\mathrm{w}^{\mathrm{t}}$ stand the Blows of Fortune," and then he says that this peace of mind is a "Greatness \& Elevation of Soul," which can "be found only in Study \& contemplation" (Letters No. I, IO). In these passages, Hume seems to discuss something similar to the Socratic indifference and magnanimity which Aristotle describes in his Posterior Analytics. Hume also seems to draw from ideas expressed in Cicero's Tusculan Disputations, which Hume explicitly cites in the letter. Cicero frequently discusses the great-souled man's peace of mind, and writes of greatness of soul ("magnitudino animi") in relation to dignity and "contempt of the vicissitudes of life" (TD II.xiii, I 49). According to Cicero, when we focus on the kind of conduct that is worthy of greatness of soul, we can even subdue "the lower part of the soul ... [and] mitigate pain as well" (TD II.xxii, 209).

At the end of his letter, Hume remarks that he is "mightily delighted" by Longinus's description of "the Character of being the great Sublime" (Letters No. I, II). In The Enquiry Concerning the Principles of Morals (hereafter EPM), Hume once again cites Longinus in much the same way he had as a teenager: "The sublime, says LONGINUS, is often nothing but the echo or image of magnanimity" (EPM 7.4/SBN 252). Thus, there is a clear connection between Hume's early idea of "Greatness \& Elevation of Soul" (Letters No. I, Io) and his later idea of "magnanimity." II

9. For more on the relation between Cicero's account of greatness and Aristotle's, see Fetter and Nicgorski (2008).

IO. For a good discussion of this letter's relation to greatness of soul, see Solomon (2000: I3 II33). Solomon does not acknowledge either the passage's relation to Aristotle's characterization of Socratic magnanimity or the importance of the letter's reference to Longinus. He does acknowledge, however, that Cicero, whom Hume mentions, also attributes greatness of soul to Socrates (I 33 ).

I I. I do not intend, here, to focus to any great extent on the relation between the notion of the sublime and the notion of greatness of soul. I discuss Longinus' work only because Hume's references to it, both in his early letter and his later work, consistently connect Hume's discussions of his modern notion of magnanimity to ancient notions of greatness. Still, how does the sublime relate to greatness? Casper C. De Jonge suggests that Longinus describes some literary authors, themselves, as possessing elevated, divine natures (20I2: 279), at least while they are employ sublime figures of speech, and their writing is just an "echo" of their great minds (288). 
In his mature work, Hume does not employ the phrase "greatness of soul," but he does tie his modern notions of "magnanimity" and "greatness of mind" to this more ancient notion. Consider the passage from EPM in which Hume cites Longinus:

Who is not struck with any signal instance of greatness of mind or Dignity of Character; with elevation of sentiment, disdain of slavery, and with that noble pride and spirit, which arises from conscious virtue? The sublime, says Longinus, is often nothing but the echo or image of magnanimity; and where this quality appears in any one, even though a syllable be not uttered, it excites our applause and admiration; as may be observed of the famous silence of Ajax in the Odyssey, which expresses more noble disdain and resolute indignation, than any language can convey. (EPM $7.4 / \mathrm{SBN}$ 252)

Here, Hume inextricably links "greatness of mind," "the sublime," and "magnanimity," and ties them to Longinus's ancient notion of greatness. Hume also provides an even more ancient example of an individual possessing these traits, namely Ajax of Homer's Odyssey, to whom Aristotle, in his Posterior Analytics, attributes greatness of soul. In the passage from the Posterior Analytics discussed in section I.I, above, Aristotle refers to Ajax's suicide, and Hume here refers to a passage from Homer's Odyssey in which Ajax, who has killed himself and is now in the underworld, remains angry and refuses to speak to Odysseus (Homer I970: 549-550).

In On Great Writing (On the Sublime), Longinus too implies that Ajax possesses elevation of mind, a quality which Alessandro Schiesaro notes that Longinus closely connects to greatness of soul (Schiesaro 1997: 99, particularly n. I7). Longinus writes that the sublime "is the echo of a noble mind" (Sublime I2), and then almost immediately suggests that, even though Ajax remains silent in the Odyssey, Ajax's thought can lead us to admire him "because of its inherent nobility" (I2). When Hume refers to Longinus and Ajax in EPM, Hume draws connections between his modern notion of greatness of mind and ancient notions of nobility and greatness.

I suspect Martin is right that greatness of mind is not, for Hume, itself a particular virtue, but is rather a category of "heroic" virtues which includes, in addition to magnanimity, "courage, intrepidity, ambition, [and] love of glory" (T 3.3.2.13/ SBN 599; Martin I992: 385). But, in his account of greatness of mind, Hume nonetheless draws on, and provides a re-interpretation of, the kind of particular virtue Aristotle describes in his account of greatness of soul. 


\section{I.3. Hume's Magnanimity and the Three Core Traits}

This section describes Hume's account of those who possess Socratic magnanimity, again focusing on their moderate response to fortune, worthiness of honor, and their virtues of justice and benevolence. I argue that, while Aristotle leaves open the question of whether Socrates's greatness is the same as that of Achilles and Ajax, Hume offers a clear-if indirect-answer. Not only is Socratic magnanimity different, but it is also superior and worthy of far greater praise, in large part because it includes benevolence as a necessary ingredient. By emphasizing and elevating Socratic magnanimity, Hume affects a shift from the ancient emphasis on courage to a modern emphasis on social virtues.

Hume is clear that Socrates is magnanimous, and that Socratic magnanimity relates to tranquility and indifference: "Who admires not Socrates; his perpetual serenity and contentment, amidst the greatest poverty and domestic vexations; his resolute contempt of riches, and his magnanimous care of preserving liberty?" (EPM 7.I7/SBN 256). ${ }^{\mathrm{I} 2}$

While Aristotle writes about Socrates's indifference to fortune, Hume writes about "philosophical tranquility," which is superior to "each assault of adverse fortune" (EPM 7.I6/SBN 256). According to Hume, "the sage elevates himself above every accident of life" (EPM 7.I6/SBN 256). Hume relates this "indifference to fortune" to magnanimity: "The nearer we approach in practice, to this sublime tranquility and indifference... the more greatness of mind we shall discover to the world. The philosophical tranquility may, indeed, be considered only as a branch of magnanimity" (EPM 7.I 6/SBN 256).

Granted, the mature Hume rejects or distances himself from many of the tenets of Cicero and the ancient Stoics, ${ }^{13}$ and the philosophical tranquility he describes should not be understood as being as extreme as theirs. I suspect that it is similar to the moderate response to fortune exhibited by Aristotle's great souled individual, who is never "overly-pleased at good fortune, nor overly-distressed at bad" (EN I I 24aI4-I 8, I 49).

Like Aristotle, Hume reflects on the relation between Socrates's magnanimity and the magnanimity possessed by heroic warriors such as Achilles and Ajax.

I 2. I do not mean to imply that Hume and Aristotle hold identical stances on what Socratic indifference is like. For Hume, Socrates' indifference involves a "resolute contempt of riches." Whether or not the same is true according to Aristotle is a question beyond the scope of this paper. As discussed in section I.2, Hume's account of greatness draws from Longinus, and I suspect his talk of "contempt of riches," here, does as well. Longinus writes: "Wealth, honors, reputation, absolute power . . . these no sensible man would count as blessings, since to despise them is itself no mean blessing. Rather than those who possess these things, men admire those great souls who could possess them but in fact disdain them" (Sublime 9).

I3. See, for one of many examples, Hume's extended critique of the ancient Stoics in his essay "The Stoic" (EMPL I 46-I 54). 
Shortly after describing Socrates's magnanimity, Hume writes that the "heroes in philosophy as well as those in war and patriotism have a grandeur . . . which astonishes our narrow souls" (EPM 7.I 8/SBN 256). Aristotle writes that Ajax, a hero of war, is magnanimous for his "intolerance of insults" and Hume claims that Ajax's "magnanimity" is recognizable in his "noble disdain and resolute indignation" (EPM 7.4/SBN 252).

Yet, while Aristotle's Posterior Analytics leaves open the question of whether Socrates possesses the same kind of magnanimity as heroic warriors, Hume is very clear that Socratic magnanimity, which is only a "branch" of magnanimity (EPM 7.I6/SBN 256), is different from warrior magnanimity. As Graham Solomon argues, Hume suggests that Socratic magnanimity is a civic virtue that need not be paired with military or grand political accomplishment (2000: I30). In his early letter to Michael Ramsey, Hume is clear that the philosopher's "Greatness \& Elevation of Soul" can "be found only in Study \& contemplation" (Letters No. I, IO); Socratic magnanimity is found in study, not in Homeric battles. Granted, according to Hume, Socrates also has a "magnanimous care of preserving liberty" (EPM 7.I7/SBN 256), and Socrates's actions did, in fact, have political significance, but they are certainly not of the same grand kind as those performed by Alcibiades, Achilles, or Ajax, those figures with whom Aristotle contrasts Socrates. ${ }^{14}$

Hume distances magnanimity from its ancient connection to heroic battles, choosing to describe as magnanimous a number of individuals who are not military heroes. For example, as Solomon suggests, Hume claims that Cleanthes - who is not a military genius - is a magnanimous individual (2000: I36). Cleanthes seems to possess Socratic magnanimity, which is tied to tranquility in fortune:

That cheerfulness, which you might remark in [Cleanthes], is not a sudden flash struck out by company: It runs through the whole tenor of his life, and preserves a perpetual serenity on his countenance, and tranquility in his soul. He has met with severe trials, misfortunes as well as dangers, and by his greatness of mind [emphasis added], was still superior to them. (EPM 9.2/SBN 269-70)

Like Socrates, Cleanthes is not only magnanimous, but genuinely virtuous, "a model of perfect virtue" (EPM 9.2/SBN 269-70) who has the greatest personal merit.

I4. Hume seems to allow for the possibility that even a philosophic sage, who is largely detached from the "bustle of the world, and drudgery of business" (EHU 5.I/SBN 40) could achieve Socratic magnanimity, acquiring "magnanimous firmness" (EHU 5.I/SBN 40). So I am hesitant to claim that, according to Hume, political action is of key importance to Socratic magnanimity. I imagine that a magnanimous sage, separate from the "bustle of the world," might very well be less engaged in political action than the average person. 
I do not intend to imply that, according to Hume, we ought to emulate Cleanthes, and in general, I do not intend to offer a strongly normative reading either of Hume's catalog of the virtues in EPM or of Hume's account of Cleanthes's exemplary character. My intent is different; I mean only to suggest that, according to Hume, someone who possesses Socratic magnanimity must also possess a wide array of other virtues. Focusing on Hume's account of Cleanthes is useful for this purpose.

Hume does not dismiss warrior magnanimity entirely. In his Treatise on $\mathrm{Hu}$ man Nature (hereafter T), he allows that even a military hero who achieves atrocious ends ${ }^{15}$ can nonetheless have "something so dazzling in his character, the mere contemplation of it so elevates the mind, that we cannot refuse it our admiration" (T 3.3.2.I 5/SBN 60I). But Hume grants that "men of cool reflection" are not inclined to praise this kind of warrior magnanimity ( $\mathrm{T} 3 \cdot 3.2 .15 / \mathrm{SBN} 600-60 \mathrm{I})$, and, as suggested, Hume allows that a more praiseworthy magnanimity is possible for individuals such as Socrates. Hume is clear that Socratic magnanimity is different from warrior magnanimity; "men of cool reflection" are inclined to praise the former, but not the latter. Socratic magnanimity is worthy of the highest praise.

Like Aristotle, Hume emphasizes the importance of deserving honor, fame, and admiration rather than claiming it. Aristotle suggests that it is of key importance that a magnanimous person be correct when he believes himself worthy of great things. Hume, in his discussion "of greatness of mind," likewise insists that "nothing can be more laudable, than to have a value for ourselves, where we really have qualities that are valuable" (T. 3.3.2.8, $38 \mathrm{I}$ ). But Hume also stresses that, if we believe ourselves to be worthy of great things and are not, in fact, worthy, then we are guilty of a vicious pride, "an over-weaning conceit of ourselves" which "causes uneasiness in all men" ( $\mathrm{T} 3 \cdot 3 \cdot 2.7 / \mathrm{SBN} 596)$.

Hume is clear that it would be an error-and contrary to "good-breeding"to let other people see that we experience substantial pride or vanity, even if it is warranted ( $\mathrm{T}$ 3.3.2.I0/SBN 597-8). It is equally clear that a great individual should experience "well grounded" pride, even if he must conceal it from others: "A genuine and hearty pride, or self-esteem, if well-conceal'd and well founded, is essential to the character of a man of honour" ( $\mathrm{T}$ 3.3.2.I I/SBN 598). Hume writes:

Nothing is more useful to us in the conduct of life, than a due degree of pride, which makes us sensible of our own merit, and gives us a confidence and assurance in all our projects and enterprizes. Whatever capacity any one may be endow'd with, 'tis entirely useless to him, if he be not acquainted with it, and form not designs suitable to it. ( $\mathrm{T} 3 \cdot 3 \cdot 2.8 / \mathrm{SBN} 596-7$ )

I 5. Hume mentions: "The subversion of empires, the devastation of provinces, the sack of cities" (T 3.3.2.I 5/SBN 60I). 
For Hume, it is of key value that a person be deserving and worthy of honor and fame, and that the individual recognize his own merit. This gives him confidence and assurance in his endeavors. A person of merit should experience warranted pride even if, according to good-breeding, he also ought to hide that pride from others. ${ }^{16}$ We return to a discussion of "good-breeding" in this essay's section 2.3 .

According to Hume, the sentiment of pride "may be either good or bad, according as it is well or ill founded" (EPM App. 4.3n/SBN 3 I4); the only good pride is warranted pride. ${ }^{17}$ This kind of "steady and well-establish'd pride and self-esteem" is that which "we call heroic virtue, and admire under the character of greatness and elevation of mind" (T 3.3.2.I3/SBN 599). According to Hume, the great-souled man strives to be deserving and to actually have the merit that warrants his great pride.

I argue that, according to Hume, those military heroes who fall short in modesty, benevolence, and justice, also fail to achieve the greatest, or best, kind of magnanimity. Without social virtues and "qualities immediately agreeable to others" (T 3.3.I.29/SBN 590), an individual's qualities and accomplishments cannot warrant the greatest degree of pride or greatness of mind. Hume agrees, at least roughly, with Aristotle: an individual with Socratic magnanimity must be generally virtuous, possessing all of the excellences.

In his early work, "An Historical Essay on Chivalry and Modern Honour" (hereafter Honour), Hume does not explicitly mention greatness of mind or magnanimity, but he clearly discusses the same heroic individual addressed in his discussion of greatness in T. Writing about the "poetic" heroes of ancient history (Honour II I , III 2), Hume discusses "the first Grecian Heroes, as they are celebrated by Homer" (Honour II8) - presumably figures such as Achilles and Ajax - in addition to "Hercules, Pirithous, Theseus, Jason, \& others of that Breed" (Honour II Io). Hume claims that while these figures are courageous, they still fail to achieve what Hume calls "the most elevate \& refin'd Courage" (Honour II I2). Hume acknowledges that their chief virtue is courage, and he implies that they possess what he later calls greatness of mind. But Hume also acknowledges that they lack the best kind of greatness, and even lack the best kind of courage. Comparing these "poetic" heroes to later "Romantic Heroes" who adhered to the rules of chivalry, Hume writes:

I6. This is a key theme of Benardete's excellent work, which treats it in a very different context. See Benardete (2013: 24-29).

I7. Jacqueline Taylor offers a very good discussion of the role pride plays as a virtue in Hume's account, acknowledging, many other points, the importance of warrant and merit (Taylor 20I2: $39-40,42-43$ ). She also provides an in-depth discussion of pride that takes into account that "some forms of pride are virtuous while others are vicious" (Taylor 20I 2: 4I), citing many of the passages I discuss only briefly. In contrast, she does not focus on the relation between love of fame and virtue, nor does she consider Socrates, or the particular role his magnanimity plays in Hume's account. 
Upon this is founded, that first \& most remarkable Difference, betwixt the poetic \& Romantic Heroes, \& indeed betwixt the great Men of the first antient History $\&$ first modern, that tho' they both valued themselves upon their Bravery above all other Virtues, in the first it bore that Air, which naturally attends it when not corrected by Reason or better Example, of Savageness \& Barbarity, which converted them in a manner into Pirates \& Robbers; whereas the second, from an affection of Civility, endeavor'd to throw into all their Behavior, the most courteous \& humane Air imaginable \& that sublime Generosity, which alwise attends the most elevate \& refin'd Courage. (Honour II I 2)

Hume implies that these ancient heroes, who lack social virtues, would also fail to achieve "the most elevate \& refin'd Courage" since they lack "the most courteous \& humane Air imaginable \& that sublime Generosity." I8 In order to achieve the greatest kind of courage-and, I would suggest, the best kind of greatness of mind-an individual must possess more social virtues, such as those belonging to the category of virtues Hume calls "benevolence": "generosity, humanity, compassion, gratitude, friendship, fidelity, zeal, disinterestedness, [and] liberality" (T $3 \cdot 3 \cdot 3 \cdot 3 / \mathrm{SBN} 603)$. Granted, an individual could be courageous and possess greatness of mind without benevolence; he just could not possess the best or highest sort of greatness. ${ }^{\text {I9 }}$

Hume implies that this is true in other contexts as well. He writes that the best sort of great-minded individual, who has a "generous, or noble disposition" and "true dignity and elevation of mind" (EPM 8.I I/SBN 265-6), experiences a desire or love of fame (EPM 8.I I/SBN 265-6; EPM 9.Io/SBN 276). Hume further suggests that this love or desire for fame is "inseparable from virtue" (EPM 8.I I/ SBN 265-6), and that noble individuals who possess this desire and love achieve "a certain reverence for themselves as well as others; which is the surest guardian

I8. As suggested in section I.2, Hume acknowledges that his conception of the sublime owes a debt to Longinus, and Hume's reference to sublime generosity should owe a similar debt. Hume also belongs to an early-modern tradition of using the term "generosity" in relation to magnanimity, glory, and pride. For example, Hobbes earlier writes: "The force of Words, being . . . too weak to hold men to the performance of their Covenants; there are in mans [sic] nature, but two imaginable helps to strengthen it. And those are either a Feare of the consequence of breaking their word; or a Glory, or Pride in appearing not to need to breake it. This latter is a Generosity [emphasis added] too rarely found to be presumed on" (L I.I 4, 70). And Leo Strauss argues that Hobbes' own theory of generosity, glory, and magnanimity itself borrows from Descartes' theory, from Passions de l'ame, of the notion of générosité, which Strauss describes as the moral correlate of "the self-confidence of the ego grown conscious of its independence and freedom" (I963: 56).

I9. While Benardete does not commit himself to this position, or discuss Hume's essay on modern honor, he does write that it might be possible to read Hume as suggesting that great-souled individuals, or at least those great-souled individuals of the highest personal merit, might also need to possess virtues or qualities are that useful and beneficial to others $\left(20 \mathrm{I}_{3}: 34-35,39,45\right.$.) 
of every virtue" (EPM 9.IO/SBN 276). ${ }^{20}$ Taken in total, Hume implies that the best sort of great-minded individual, who experiences a love of fame, would also possess many other virtues, including those that involve a "reverence for . . . others," such as benevolence.

Hume reiterates this point in his essay "Of the Dignity or Meanness of Human Nature," writing:

Vanity is so closely allied to virtue, and to love the fame of laudable actions approaches so near the love of laudable actions for their own sake, that these passions are more capable of mixture, than any other kinds of affection; and it is almost impossible to have the latter without some degree of the former. (EMPL 86)

This passage from EMPL is thematically linked to those of EPM 8.I I and 9.10, discussed in the previous paragraph. According to EPM, the love of fame cannot be separated from virtue. According to EMPL, those who "love the fame of laudable actions" possess vanity, which is "closely allied to virtue." In EPM, Hume suggests that the best sort of great-minded individual possesses a love of fame which cannot be separated from virtue. According to EMPL, since this individual possesses this kind of fame, he or she would also possess virtuous vanity. Because the passage from EMPL appears in a context that emphasizes the importance of social passions and social virtues, we should take its term "virtue" to refer to benevolent virtues such as kindness and friendship, among others. So, the individual with the best sort of greatness possesses a kind of vanity that is tied to benevolent virtues. Someone who has the best sort of greatness would also be benevolent, and without some degree of vanity, this benevolence would be "almost impossible."

If individuals who exhibit the best sort of greatness-and who must be benevolent-also experience greater well-founded pride as a result, we could conclude that there is a level of pride that can only be grounded by virtue. I will leave this point not entirely resolved, because Hume does not explicitly address it. But Hume does imply_and this is telling — that individuals with benevolent virtues would take pride in those virtues. He claims this is true by the very nature of virtue (T 2.I.7.5-8/SBN 296-298). So, other things being equal, it would seem that benevolent individuals experience greater well-founded pride than those who are not.

Setting pride aside, if we focus on Hume's discussions in Honour and T, which connect greatness, fame, and social virtue, we can easily conclude that, for Hume, only a genuinely benevolent individual can achieve the best sort of greatness of

20. Schliesser also discusses the relation between Hume's love of fame and virtue; see in particular (2003: 334-335). 
mind. So Martin is wrong to suggest that, in Hume's account of human excellence, greatness of mind is only of secondary importance (1992: 389). Martin acknowledges that Hume emphasizes both benevolence and greatness of mind in his accounts of human excellence (1992: 384 ), ${ }^{2 \mathrm{I}}$ but Martin nonetheless suggests that Hume weights more heavily those virtues associated with benevolence that correspond to our social nature. But this seems mistaken. After all, benevolence is itself a necessary ingredient in the best sort of greatness of mind.

Granted, Martin is correct to stress that, for Hume, "courage and ambition, when not regulated by benevolence, are fit only to make a tyrant and a public robber" ( $\mathrm{T} 3 \cdot 3 \cdot 3 \cdot 3 / \mathrm{SBN} 604)$. But this does not suggest that benevolence is more important than courage. For Hume, there are different kinds or levels of courage, only the best of which demands benevolence and social virtue. This passage suggests that lower kinds of courage can be dangerous. So, while benevolence is necessary for the best courage (and so should not be weighted more heavily), so too is benevolence the difference between a dangerous quality and a good one (and so should be weighted equally).

Note that, similar to the passage just quoted from T, in Honour Hume writes that people who have "Bravery" but lack a "courteous \& humane Air" become "Pirates and Robbers." But in Honour, Hume also acknowledges a point that remains true in his later work: if you're a pirate or a robber, you do not possess the best sort of courage, either.

I hypothesize that perhaps the mature Hume chooses to use the term "greatness of mind" rather than the older "greatness of soul" in part to distinguish his account of greatness from those of ancient authors, who perhaps-from Hume's view-do not weight benevolence heavily enough. I suspect that Hume is trying to affect a shift, from the ancient "rude ages" (Honour I77) in which courage "is alwaise the most admir'd Virtue" (Honour II7), to modern times, in which benevolence is given its due. ${ }^{22}$ To this end, Hume writes that ancients would "consider as romantic and incredible, the degree of humanity, clemency, order, tranquility and other social virtue ... we have attained in modern times" (EPM 7.I8/SBN 256-257). This does not mean that Hume ceases to weight quite heavily his conception of greatness; it just means that he changes what "greatness" means so that it clearly contains benevolence in it. As suggested, Hume explicitly acknowledges his debt to ancient notions of greatness, to which his own notion bears similarities,

2I. Martin cites as examples of descriptions of human excellence Hume's discussion of Cleanthes (EPM 9.2/SBN 269-70), in addition to ( $\mathrm{T} 3 \cdot 3 \cdot 3.9 / \mathrm{SBN} 606$ ) and ("The Sceptic," EMPL I68). I suspect she could also have included Hume's description of Montrose, which she later touches on (I992: 388 ), in relation to greatness of mind. Hume writes of Montrose that "Whatever was sublime, elegant, or noble touched his great soul [emphasis added]. Nor was he insensible to the pleasures either of society or of love [emphasis added]" (History 24).

22. For more on this shift, see Hanley (2007) and Wright (2012). 
but he nonetheless provides a novel approach.

\section{I.4. Adam Smith and Greatness of Soul}

Smith, too, offers a unique re-interpretation of Socratic greatness of soul that nonetheless focuses on the same three characteristics: an "indifference" to fortune; an emphasis on deserving honor rather than claiming it; and the possession of great virtue. This section prepares for the second half of this paper, which discusses Smith's "Letter to Strahan," in which he attributes Socratic greatness to David Hume. This section is too brief to provide a complete account of the divergences between Hume's and Smith's account of the virtues, and is meant only as a brief overview.

Smith explicitly provides an interpretation of ancient systems of philosophy like those of Plato, Aristotle, Zeno, and other Stoics" ${ }^{23}$ which emphasize, "the great, the awful, and the respectable virtues, the virtues of self-government, and selfcommand [emphasis added]; fortitude, magnanimity, independency upon fortune [emphasis added], the contempt of all outward accidents, of pain, poverty, exile, and death" (TMS VII.ii.4.2, 306).

Smith touches on ancient magnanimity, and ties it directly to "independency upon fortune," in a way not unlike Aristotle's discussion in Posterior Analytics. But Smith criticizes the ancient philosophers-particularly the Stoics-for their complete indifference to fortune. ${ }^{24}$ Smith attests that we ought to care about life, and be upset by bad fortune and pleased by good. He criticizes the Stoic philosophy because "It endeavours to render us altogether indifferent and unconcerned in the success or miscarriage of every thing which Nature has prescribed to us as the proper business and occupation of our lives" (TMS VII.ii.I.47, 292-293). In fact, we ought not be indifferent to-we instead ought to care about-those events which, by nature, interest us the most, namely events that "immediately affect ourselves, our friends, [and] our country" (TMS VII.ii.I.44, 292)..$^{25}$

Smith rejects the Stoics' account of what constitutes an appropriate response to fortune. ${ }^{26} \mathrm{He}$ nonetheless recognizes that a great-souled individual must respond to fortune moderately. He writes, for instance, that our passionate response to fortune should never be "too vehement" (TMS VII.ii.r.44, 292). Smith pro-

23. Smith discusses these three philosophers, in turn, in TMS VII.ii.I.I-47, 267-292.

24. Smith discusses the Stoic indifference extensively in TMS VII.ii.I; in particular see paragraphs 2 I and 24, pages 277 and 279. I do not mean to imply, here, that Smith entirely rejects what the ancient Stoics say. In fact, he sometimes clearly draws on their work; for example, see footnote 43 .

25. For more on how Smith's critique of Stoicism relates to his discussion of self-command, see Hanley (2009: I72-I73).

26. For numerous arguments against interpreting Smith as a Stoic, see Schliesser (2008). 
vides his own, unique theory of how an appropriate, moderate response to fortune might look:

A fretful temper, which feels with too much sensibility, every little cross accident, renders a man miserable in himself and offensive to other people. A calm one, which does not allow its tranquility to be disturbed, either by the small injuries, or by the little disasters incident to the usual course of human affairs . . . is a blessing. (TMS VI.iii.I7, 244)

Smith claims that we should not let our tranquility be disturbed by "small injuries" or "every little cross accident." But this does not mean we should be uncaring, and have a "stupid insensibility to the events of human life" (TMS VI.iii.I 8, 244). While we should not be disturbed by small things, a virtuous person, "feels the full distress of the calamity which has befallen him . . . but . . . feels more strongly what the dignity of his own character requires; [and] does not abandon himself to the guidance of undisciplined passions" (TMS VI.iii.I 8, 245).

Smith's claim sounds markedly similar to Aristotle's account of the great-souled individual's response to fortune. Remember that Aristotle's great-souled individual, as described in EN, is not completely indifferent to fortune, but is instead moderately disposed to it, never "overly-pleased at good fortune, nor overly-distressed at bad" (EN I I 24a I4-I 8, I 49). Recall, too, that Aristotle's magnanimous individual does not take seriously, or complain about, his small problems (I I 25a4-I I, I 5 I), which, in Smith's language, are "little cross accidents" and "small injuries."

Smith acknowledges that his account of greatness draws from Aristotle's ancient account of greatness of soul. Recall that, for Hume, the sentiment of pride "may be either good or bad, according as it is well or ill founded" (EPM App. 4.3n/ SBN 3 I 4), and that well-founded pride is what we call "heroic virtue" or greatness of mind (T 3.3.2.I3/SBN 599). Smith similarly claims that the words "proud and pride ... are sometimes taken in a good sense" (TMS VI.iii.44, 258), like when we speak of "noble pride." Smith suggests that "pride is, in this case, confounded with magnanimity" (TMS VI.iii.44, 258). Immediately after making this claim, Smith leaps into a discussion of Aristotle-in particular Aristotle's notion of greatness of soul. So, when Smith refers to "magnanimity" in TMS VI.3 and throughout his work as a whole, it should be clear he has in mind something like what Aristotle describes as greatness of soul.

Hanley correctly acknowledges that Smith's account of "self-command" in VI.3 is particularly concerned with the self-command of heroes and statesmen, which Smith identifies with what "the ancient moralists . . . alluded to" as "fortitude, manhood, and strength of mind" (TMS VI.iii.3, 238; Hanley 2009: I 59). These passions, Smith suggests, give us control over "fear and anger" (TMS VI.iii.3, 238). 
Hanley acknowledges that, when Smith later focuses on ancient philosophy, he returns to the idea of self-command, and identifies it with the ancients' conception of "fortitude and magnanimity" (TMS VII.ii.I.7, 268), which enable an individual to "check and restrain the inferior and brutal appetites" (TMS VII.ii.r.7, 268). It appears that Smith's chapter on self-command-even independent of its references to "magnanimity" — can be understood in reference to the ancients' conception of "greatness of soul."

This is most clear in Smith's discussion of the relation between self-command and virtue. Smith attests that someone who acts "according to the dictates of prudence, of justice, and proper beneficence" even in the midst of "the greatest dangers and difficulties" shows great self-command and "the character of the most exalted wisdom and virtue" (TMS VI.iii.II, 24I). Then Smith writes, "Self-command is not only itself a great virtue, but from it all other virtues seem to derive their principle lustre" (TMS VI.iii.I I, 24I). This seems almost identical to Aquinas's assertion that not only is magnanimity a virtue, but also that "further lustre is added by the very greatness of a virtuous deed because of magnanimity, which in Aristotle's words makes all virtues greater" (ST II-II, Q. I29, Art. 4, ad. 3, II3). Likewise, Smith's claim resonates with Aristotle's contention that, "greatness of soul, then, seems to be a sort of adornment, as it were, of the excellences" (I I $23 \mathrm{~b}_{3} \mathrm{O}-3 \mathrm{I}$ ). Smith's notion of "self-command" shares clear similarities with Aristotle's (and with Aquinas's) greatness of soul.

Granted, according to Smith, not every person of great self-control and greatness of soul is virtuous in every respect. For Smith, a person could lack justice and beneficence, and still exhibit self-command, magnanimity, and greatness of soul.

Nor does this magnanimity give lustre only to the characters of innocent and virtuous men. It draws some degree of favourable regard even upon those of the greatest criminals . . . we often cannot help regretting that a man who possessed such great and noble powers should have been capable of such mean enormities. (TMS VI.iii.6, 239)

Likewise, Smith insists that "the command of fear, the command of anger" which he identifies with self-command, greatness of soul, and magnanimity, are not always directed by justice and benevolence: "The most intrepid valour may be employed in the cause of the greatest injustice" (TMS VI.iii.I2, 24I).

In writing about those who are both unjust and magnanimous, Smith picks up on Hume's language. Hume suggests that when "men of cool reflection" fix their view on a great military hero whose action is evil, they sometimes find "there is something so dazzling in his character, the mere contemplation of it so elevates the mind, that we cannot refuse it our admiration" (T 3.3.2.1 $5 / \mathrm{SBN}$ 60I). Smith 
likewise suggests that "even the man of sober judgment often abandons himself to the general admiration" (TMS VI.iii.27, 250) of those who are successful and show heroic valor, even if they are involved in great injustice (TMS VI.concl.7, 264). We cannot help but admire them for the "splendid and dazzling quality" of their exertion (TMS VI.concl.7, 264). For Smith, these unjust heroes are nonetheless magnanimous. ${ }^{27}$

Nonetheless, as suggested above, Smith also allows that a magnanimous individual may, in fact, be entirely just and beneficent. Magnanimity then adds "lustre" to all the other virtues, and increases their "splendor" (VI.3.I I-I 2.24I). In addition, Smith allows that self-command is "no doubt more loved and admired" when it is just and virtuous, than when it is not (VI.3.concl.7, 264). In praise of this virtuous self-command, Smith writes:

If he suffers in the cause of liberty and justice, for the sake of humanity ... all mix themselves with the admiration of his magnanimity [emphasis added] .... The heroes of ancient and modern history, who are remembered with the most peculiar favour and affection, are, many of them, those who, in the cause of truth, liberty, and justice, have perished on the scaffold .... Had the enemies of Socrates [emphasis added] suffered him to die quietly in his bed, the glory even of that great philosopher might possibly never have acquired that dazzling splendor. (TMS VI.iii. 5,238$)^{28}$

Smith taps into the same sort of notion of virtuous magnanimity that Aristotle discusses in EN. Smith has in mind the individual who not only possesses greatness of soul, but is also committed to justice, truth, and beneficence, much like Aristotle's great-souled man who excels in all virtues, and for whom greatness is a dazzling ornament (EN I I 23b3o-3 I). In Smith's passage, Socrates-with his sense of justice and truth-is described with the same "dazzling splendor" with which he describes military heroes.

Smith suggests that Socrates is magnanimous, just, and virtuous. This is not to say that Socrates avoids Smith's criticism. Even Socrates, according to Smith, experiences "excessive self-admiration" as evidenced by his fancy "that he had secret

27. Hanley says that these men possess "a corruption of a disposition regulated by magnanimity" (2009: I65). He provides an excellent discussion of the corrupted way in which individuals tend to admire, and give approbation to, the pernicious self-command of criminals, military heroes, etc. (Hanley 2009: I68-I70). He does not focus on the similarities between Hume's account of dazzling evil and Smith's. Further, while Hanley recognizes that, for Smith, an individual who displays selfcommand/magnanimity might be either just/beneficent or not, Hanley focuses much more attention on corrupted/pernicious magnanimity (I66-I72) than he does on just magnanimity. Hanley does not acknowledge the strong ties between Smith's language and that used by Aristotle to describe virtuous megalopsuchia.

28. For a greater discussion of this quote, see section 2.3 , in particular footnote 43 . 
and frequent intimations from some invisible and divine Being" (TMS VI.iii.28, 250-25I) (presumably the daemon Socrates mentions in Plato's Apology). ${ }^{29}$ But Smith does not claim that Socrates's magnanimity was unjust; he merely emphasizes that even those who experience just and virtuous magnanimity are inclined to experience some degree of destructive self-preference (Hanley 2009: I 65 ). ${ }^{30}$

Further, for Smith, as well as for Hume and Aristotle, magnanimity concerns primarily deserving or being worthy of honor, approbation, and applause, rather than claiming or receiving honor. It is key to the magnanimous individual that he actually be right when he believes himself to have great merit or capacity. As Hanley acknowledges (2009: I 53), Smith seems to recognize that this is the case for Aristotle, when he writes that, according to Aristotle, "Magnanimity . . . lies in the middle between the excess of arrogance and the defect of pusillanimity, of which the one consists in too extravagant, the other in too weak a sentiment of our own worth and dignity" (TMS VII.2.I.I3, 27I).

Much of Smith's TMS VI.iii focuses on an individual's own self-estimation and self-approbation, and in particular, on those who "really and justly feel themselves very much above" the "ordinary degree of excellence which is commonly attained by other people" (TMS VI.iii.27, 249). No doubt, even if magnanimous individuals tend to over-admire themselves, it seems they must at least be correct that they are better-and more worthy or deserving-than most.

As Hanley suggests, Smith is even clearer about the importance of deserving honor or applause in earlier sections of TMS. In TMS III.I-2, for example, Smith claims that people do not merely desire the "applause" of others; they also desire to deserve the applause and praise (TMS III.I.5, II2; III.2.I, II3-II4). Smith writes that, granting that we believe ourselves worthy of admiration, "We can be more indifferent about the applause, and, in some measure, despise the censure of the world; secure that, however misunderstood or misrepresented, we are the natural and proper objects of approbation" (TMS III. I.5, I I 2). Smith suggests that man desires "not only to be loved, but to be lovely" (TMS III.2.I, I I3), and that he desires "not only praise, but praiseworthiness" (TMS II.2.I, I I 4). As Aristotle and Hume suggest for the great-souled, great-minded individual, Smith also suggests that it is not enough to receive honor (praise or love); it is key that we actually be worthy of that honor. We desire that our belief in our own capacity be grounded in actual merit. ${ }^{3 \text { I }}$

29. Also see TMS VI.I.I I, where Smith writes about Socrates' "contempt of the ordinary decorums of life."

30. Hanley focuses on this tendency toward destructive self-preference, not on Socrates' particular relation to this tendency.

$3 \mathrm{I}$. Hanley, too, focuses on the importance of merit and deserving, in relation to magnanimous self-command (2009: particularly I35-I39, but throughout Chapter 5). Hanley cites his own work, "Aristotle on the Greatness of Greatness of soul," claiming that, in appealing to the love of praiseworthiness, Smith harkens back to Aristotle's conception of greatness (2009: I 50, in particular n. 28). 
Recall that, according to Aristotle, the great-souled individual considers honor, even for great things, "of small consequence” (EN I I 24a I 8-20, I 49), is only moderately pleased by honor given by people of excellence, and despises honor given for small things (EN II24a5-aI4, I49). For Aristotle's great-souled man, being worthy is more important than being honored. Similarly, Smith, writing about the "wise man," says:

To obtain the approbation of mankind, where no approbation is due, can never be an object of any importance to him. To obtain that approbation where it is really due, may sometimes be an object of no great importance to him. But to be that which deserves approbation, must always be an object of the highest. (TMS III.2.7, I I 7)

Smith says those who are pleased with "groundless applause" experience vanity, which is a "superficial levity and weakness" (TMS III.2.4, I I 5 ). In contrast, to desire or accept praise "where it is really due" is not vanity, or weakness, at all. He writes, "the love of just fame, a true glory, even for its own sake . . . is not unworthy even of a wise man" (TMS III.2.8, I I 7). We can recognize similarities between this claim and Hume's position on fame, discussed above. But Smith qualifies his assertion, writing that the wise man sometimes "neglects and even despises" just fame, particularly when he is sufficiently well-aware of his own merit (TMS III.2.8, I 7). Smith is more careful than Hume to focus on the self-approbation of praiseworthiness.

\section{I. David Hume: Adam Smith’s Great-Souled Man}

In this second half of my paper, I focus on Smith's "Letter to Strahan," published in conjunction with Hume's short autobiography, "My Own Life." I argue that Smith attributes Socratic magnanimity to Hume, suggesting that Hume: (I) responds moderately to good and bad fortune; (2) possesses the greatest virtue, and a commitment to justice and benevolence; and (3) merits and is worthy of great honor and approbation. Even more important than this conclusion are the details involved; since Hume is an exemplar of Socratic magnanimity and human excellence, by considering the details of Smith's description of Hume we can better understand both excellence and magnanimity. Further, I argue that, by convincing us of Hume's greatness, Smith encourages us to admire Hume, approve of Hume's "love of literary fame" (EMPL xl), and to seek Hume's virtues for ourselves.

I begin by focusing on (I), Hume's moderate response to fortune, and I later focus on (2) and (3). Smith quotes a letter from Hume's doctor, which claims that even when Hume was at his sickest and nearest to death, he remained "free from 
anxiety, impatience, or low spirits" (EMPL xlvii).32 Smith, himself, writes of Hume that:

His temper, indeed, seemed to be more happily balanced, if I may be allowed such an expression, than that perhaps of any other man I have ever known. Even in the lowest state of his fortune, his great and necessary frugality never hindered him from exercising, upon proper occasions, acts both of charity and generosity. It was a frugality founded, not upon avarice, but upon the love of independency. (EMPL xlviii)

This passage picks up on much of both Hume's and Smith's discussions of the great-souled response to fortune. It describes the moderate or "balanced" character of that response, in addition to the appropriate "tranquility" the great-souled individual exhibits and feels in many cases (TMS VI.iii.I7, 244; EPM 7.I6/SBN 256). Remember that, for Hume, this philosophical tranquility is one "branch" of magnanimity, the kind which, at age sixteen, Hume strongly desires when he writes in his letter of "Independency on Fortune" (Letters No. I, I0).

This is the magnanimity possessed by Socrates who showed "perpetual serenity and contentment, amidst the greatest poverty and domestic vexations" (EPM 7.I 7 /SBN 256). Hume's description of Socrates seems to anticipate Smith's claim that, "even in the lowest state of fortune, [Hume's] great and necessary frugality" never made it so that he could not live morally or remain content. As Smith himself suggests, the great-souled individual, even when facing great misfortune feels strongly "what the dignity of his own character requires" (TMS VI.iii.I 8, 245) and lives both morally and appropriately.

In Smith's short letter, focusing on Hume's dying days, he uses the words "cheerful" and "cheerfulness" seven times. This is no mere accident; it is meant to draw attention to Hume's demeanor in response to the bad fortune he faces. In TMS, Smith connects the notions of cheerfulness, the appropriate response to fortune, and magnanimity, writing:

32. My essay does not focus on the relation between Smith's letter and Hume's religious skepticism, but the connection is worth noting. Donald C. Ainslie, among others, notes that Smith also wrote the "Letter to Strahan" in response to the public's clamor to know how Hume, who held skeptical tenets about religion, would think and act as his death approached. Would he recant his skeptical beliefs, or would he-refusing to believe in the afterlife-fear and stress over his death? (Ainslie 2006: Kindle Location 3 I49). On a related but different note, Lívia Guimãres argues that, when Hume on his deathbed does not anticipate or fear the possibility of eternal punishment, he actually confirms the benefits of religious skepticism; the skeptic, after all, has far less reason to fear eternal punishment (Guimãres 2008: 25). My essay, which does not focus on this religious angle, uses Smith's "Letter" only in order to better discuss Socratic magnanimity. 
Magnanimity [emphasis added] amidst great distress appears always so divinely graceful. His behaviour is genteel and agreeable who can maintain his cheerfulness [emphasis added] amidst a number of frivolous disasters. But he appears to be more than mortal who can support in the same manner the most dreadful calamities. (TMS I.iii.I.I3, 47-48)

Smith also links Hume and Socrates together with the word "cheerful," writing that Socrates, approaching death after drinking hemlock, showed "the gayest and most cheerful [emphasis added] tranquility" (I.iii.I.I 4, 48)

Hume connects cheerfulness, fortune, and magnanimity, when, in his description of the character of Cleanthes, he writes:

That cheerfulness [emphasis added] . . . is not a sudden flash struck out by company: It runs through the whole tenor of his life, and preserves a perpetual serenity on his countenance, and tranquility in his soul. He has met with severe trials, misfortunes as well as dangers, and by his greatness of mind [emphasis added], was still superior to them. (EPM 9.2/SBN 269-70)

Hume, even in the face of the trial of his illness and the misfortune of his impending death, by dint of his magnanimity, remains superior to them, and cheerful. He avoids what Smith calls "the flat and tasteless gravity which too frequently accompanies old age" (TMS VI.iii.2 I, 246).

\subsection{David Hume and the Greatest Merit and Virtue}

It is remarkable how similar Hume's description of Cleanthes-a moral, greatsouled man-is to Smith's description of Hume. Not only is Cleanthes magnanimous, but he is also someone of the greatest personal merit (EPM 9.2/SBN 269-70). In addition to claiming that Cleanthes is magnanimous insofar has he possesses "greatness of mind" and is "cheerful," Hume also describes Cleanthes as "a man of honour and humanity," who shows "assiduous application" to study and has a "quick knowledge both of men and business," who is the "gayest company," "the life and soul of conversation," and whose "ingenious knowledge" is "genteelly delivered" (EPM 9.2/SBN 269-70).33

Smith similarly describes Hume as "magnanimous" twice. Remember that Smith explicitly discusses magnanimity in relation to Aristotle's account of greatness of soul, and uses the term repeatedly throughout his discussion of "self-

33. I do not intend to offer a strongly normative reading of Hume's account of the virtues in EPM, or of Cleanthes' character. Please see my discussion in section I.3. 
command," which itself draws heavily on Aristotle's account of greatness. This, alone, should be proof that Smith considered Hume a great-souled man, not so far different from Hume's character of Cleanthes.

Just as Hume stresses Cleanthes's pleasing role in conversation, so too Smith emphasizes Hume's "social disposition" (EMPL xlvi) and repeatedly describes Hume's spirited conversation with friends. Hume describes Cleanthes "assiduous application" to study, and his "ingenious knowledge"; Smith mentions Hume has "the most severe application, the greatest depth of thought, and a capacity in every respect the most comprehensive" (EMPL xlix). Smith also goes out of his way to display Hume as a man of honor and humanity. Finally, and perhaps most significantly, Hume suggests, of Cleanthes, that "a philosopher might select this character as a model of perfect virtue" (EPM 9.2/SBN 270). Smith similarly writes of Hume "as approaching as nearly to the idea of a perfectly wise and virtuous man, as perhaps the nature of human frailty will permit" (EMPL xlix).

Smith casts Hume not only as someone greatly virtuous, but also as someone who is worthy and deserving of the greatest honor and approbation. His worth is emphasized far more than the honor and fame he received. Additionally, Smith is careful to describe Hume as having many of those qualities that Hume, himself, claims contribute to personal merit, including: frugality, magnanimity, freedom from anxiety and pain, tenderness, good wit, good-nature, learning, and decency.

Likewise, while Smith does not explicitly call Hume "benevolent" or "beneficent," he does, as Schliesser suggests, focus on these qualities (Schliesser 2003: 340). Smith recounts a fanciful story Hume told him, based on the dialogues of Lucian, ${ }^{34}$ about what Hume would say if he were to encounter the mythological character Charon, responsible for bringing the dead to the underworld. Hume jokingly suggests that he would ask Charon to let him remain alive until his work could finally "open the eyes of the Public" and see "the downfall of some of the prevailing systems of superstition" (EMPL xlvi). As Schliesser suggests, this emphasizes Hume's desire to benefit and help mankind.

Ernst Campbell Mossner points out that, contrary to the suggestion of many of Hume's critics, ${ }^{35}$ there is nothing pernicious about Hume's "love of literary fame," which, in "My Own Life," Hume claims is his "ruling passion" (EMPL xl; Mossner I950: 200-20I). Mossner correctly recognizes that this "love of literary fame" is

34. As Annette C. Baier notes, while Smith claims that, as Hume approached his death, he was reading Lucian's "Dialogues of the Dead," the story Hume tells of Charon does not clearly relate to any section of these Dialogues, and instead plays on Lucian's “Downward Journey" (Baier 2006). Smith's account of Hume's final days includes some embellishments and inaccuracies. Additionally, as Schliesser acknowledges (2003: 356, n. 36), Smith was not present for Hume's final days, and his letter might better be treated as a depiction of Hume's character than strict historical account. Schliesser's essay points out other embellishments and inaccuracies, as well. For example, see (2003: 358, n. 48).

35. Mossner surveys the writings of several theorists who strongly criticize Hume for his vanity and desire for fame (Mossner I950: particularly I84-I 88 ). 
the same motive Hume discusses in $T$, when he writes: "I feel an ambition to arise in me of contributing to the instruction of mankind, and of acquiring a name by my inventions and discoveries" (T I.4.7.I2, I76; Mossner I950: I9 I-I92). Hume may desire "acquiring a name," but he wishes to be worthy of that name and worthy because of his merit, and the genuine assistance his philosophy can offer mankind. This seems to be the exact motive described in the story Smith recounts about Charon-to "open the eyes of the Public."

Schliesser acknowledges, as I have in part I, that, according to Hume, some people experience "good" vanity-a vanity tied to a love of fame that is "inseparable from virtue" (EPM 8.I I/SBN 265), and that prompts the individual to achieve great virtue and beneficence (EPM 9.Io/SBN 276; EMPL 86; Schliesser 2003: 334-335). Schliesser also notes that, in "My Own Life," Hume hopes any vanity he experiences is the right sort: "I cannot say there is no vanity in making this funeral oration of myself, but I hope it is not a misplaced one" (EMPL xli; Schliesser 2003: 334-335).

Smith, in contrast, strongly implies that to desire praise "where it is really due" is not vanity at all (TMS III.2.8, I I 7). In his "Letter to Strahan," Smith is clear that Hume is truly worthy and deserving of praise and approbation, and is worthy, in large part, because of his great virtue and beneficence. So Hume, who is worthy of the fame he loves, is not vain at all. ${ }^{36}$ As Schliesser suggests, we can take Hume's "love of literary fame" to be the "love of just fame" which Smith writes "is not unworthy even of a wise man" (TMS III.2.8, II 7; Schliesser 2003: 342, 344). It is the love of fame that belongs to those who are great-souled, and particularly those who are just and beneficent.

Remember that, according to Smith, Socrates achieves a "dazzling splendor" (TMS VI.iii.5, 238) once his just, virtuous magnanimity is revealed to us by his response to his trial and forthcoming death. Recall too that we are, by our nature, drawn to admire someone who is magnanimous, whether or not he is just, because of the "splendid and dazzling quality" of his exertion (TMS VI.concl.7, 264; TMS VI.iii.28, 250). Hume goes so far as to suggest: "there is something so dazzling in his character, the mere contemplation of it so elevates the mind, that we cannot refuse it our admiration" ( $\mathrm{T}$ 3.3.2.I $5 / \mathrm{SBN}$ 60I). Magnanimity has an aesthetic side, which dazzles us into a favorable response. ${ }^{37}$

36. While Schliesser acknowledges that, for Smith, the word "vain" can never be "taken in a good sense" (2003: 336; see also TMS, VI.iii.43, 258), Schliesser nonetheless maintains that, according to Smith, a virtuous and fully-deserving individual who loves just fame is nonetheless vain, and vain in a good way. Schliesser suggests that, according to Smith, such an individual does not deserve to be called vain, because the word "vain" is never taken in a good sense, but the person is vain in a good way, regardless (2003: 342-343). I read Smith differently. To be vain (not just to be "called" vain) it is necessary to desire and accept praise where no praise is due (I take TMS III.2.8 to be good evidence of this). So, the fully-deserving, virtuous person who loves just fame is not really vain at all.

37. Benardete's discussions of the ability of magnanimity to "dazzle" us are excellent (2013: $5-7,33)$. 
We would be wrong to praise-and perhaps even to admire-magnanimous individuals who are unjust and cruel. Nonetheless, even philosophers of cool reflection often mistakenly admire them. There is something about a person's magnanimity that tends to demand our admiration, regardless of his vices. Of course, those magnanimous people who are genuinely worthy of our praise, and who "are remembered with the most peculiar favour and affection" (TMS VI.iii. 5, 238), are those who are also committed to truth, justice, and beneficence. Smith is clear that we most love and admire magnanimous people who are also the most virtuous (VI.3.concl.7, 264).

By convincing us of Hume's magnanimity, Smith encourages us to look up to Hume. Hume's magnanimity compels our admiration. And just as men of sober judgment often cannot help but admire magnanimous warriors, regardless of whether they are just or not, so also we might be inclined to admire Hume, perhaps, even if we disagree with his philosophy. Insofar as Smith also stresses Hume's great virtue-his frugality, benevolence, good wit, justice, and decencySmith encourages us to recognize Hume as genuinely praiseworthy, in addition to admirable. Thus, we will love and admire Hume. Hume is a genuinely great-souled man, worthy of the approbation he receives from us.

Hanley argues that Hume, in "My Own Life," presents himself as a character whom his audience might wish to emulate, to encourage them to acquire his "studious disposition," "industry" (EMPL xxxiii), and "rigid frugality" (EMPL xxxiv), which enabled Hume to successfully satisfy his vanity while achieving, by the end of his life, a good degree of wealth (Hanley 2002a: 66I-662, 676-677). ${ }^{38}$ Smith's letter seems to support Hume's project. 39 If the letter hits its mark, it guarantees that we will admire Hume, and for good reason. And insofar as we are likely to seek to emulate those whom we admire for good reason, Smith encourages us to emulate Hume. He dazzles us into pursuing those virtues Hume possesses-Hume, who was "approaching . . . the idea of a perfectly wise and virtuous man" (EMPL xlix).

Likewise, too, if we recognize Hume's love of fame as a virtue that enabled him to achieve great deeds, we might seek to act from similar motives, ourselves. Overall, we come to better recognize the positive value of magnanimity; it was an essential component of, and a driving force behind, David Hume.

38. Donald C. Ainslie similarly suggests that, in Hume's "Life," he emphasizes those aspects of his life which, in $T$, he claims are the main causes of the esteem we have for other people (the main causes of our indirect passions, more generally). Hume emphasizes his bodily attributes, virtues, socioeconomic status, and "external advantages" such as family background (Ainslie 2006: Kindle Location 3234). So, again, we can take Hume to be presenting himself as someone his audience might esteem and wish to emulate.

39. Hanley seems to imply this conclusion, though for different reasons (2002a: 682-68). 


\subsection{Manners and Death: Revealing Hume’s Greatness}

Smith's "Letter to Strahan" uniquely displays Hume's greatness chiefly because it focuses on Hume's demeanor and behavior during the final days of his life, when he sees death looming, and when sickness leaves him weak. When facing death, a person can display his magnanimity fully, and without any impropriety.

In the life of a philosopher, there might rarely be suitable opportunities for displaying greatness. In fact, Hume suggests that typically individuals must, in accordance with good manners, conceal their well-founded pride and magnanimity from those around them. Smith's "Letter to Strahan" takes advantage of a rare opportunity, using his discussion of Hume's final days to reveal a greatness that might otherwise have remained hidden.

Hume claims that, typically, a person's expressions of his own pride are "contemn'd" by other people and lead to the "greatest indignation in each other" ( $\mathrm{T}$ 3.3.2.IO/SBN 597). Since most people are prone to over-value themselves, and this ill-founded pride or "over-weaning concept" is so disagreeable, we have come to generally condemn expressions of pride, even if they come from "men of sense and merit" whose pride really is well-founded ( $\mathrm{T}$ 3.3.2.10/SBN 597). $4^{\circ}$

Thus Hume suggests that, if we are prideful, we should conceal that pride from other people (T 3.3.2.IO-I I/SBN 597-599). The rules of good-breeding, or goodmanners demand this. As Hume writes in EPM:

Custom has established it as a rule, in common societies, that men should not indulge themselves in self-praise, or even speak much of themselves, and it is only among intimate friends or people of very manly behaviour, that one is allowed to do himself justice. (EPM 8.9/SBN 264)

Recall that, for Hume, "nothing is more useful to us in the conduct of life, than a due degree of [well-founded] pride" ( $\mathrm{T}$ 3.3.2.8/SBN 596), which gives us confidence and guides us toward success. So Hume suggests that men of "sense and merit" should, in fact, feel and acknowledge their pride, but they should conceal it from other people:

If we harbour pride in our breasts, we must carry a fair outside, and have the appearance of modesty and mutual deference in all our conduct and

40. For a good discussion of Hume's principles of sympathy and comparison, and their role in our response to other people's expressions of their pride, see Brand (20I0). I generally agree with his approach, but (as implied above) disagree that a magnanimous individual must be sincere in his expressed doubt about his own intrinsic value (Brand 2010: 349). For very good discussions of the mechanisms behind Hume's approach to pride, also see Davidson (I976), Baier (I978), and Ardall (I989). 
behaviour .... A genuine and hearty pride, or self-esteem, if well conceal'd and well founded, is essential to the character of a man of honour. ( $\mathrm{T}$ 3.3.2.10/SBN 598)

Hume says the same of well-founded vanity as he does of pride. It, too, must be felt but concealed ( $\mathrm{T}$ 3.3.2.IO/SBN 597-8). Recognizing this, the opening line of Hume's "My Own Life" reads like the punch-line of a witty joke: "It is difficult for a man to speak long of himself without vanity; therefore, I shall be short" (EMPL xxxi). Provided Hume takes his own advice, he experiences well-grounded vanity and pride, but must, according to good-breeding and manners, conceal them. So his autobiography is less than fifteen pages long.

Recall from part I that, according to both Hume and Smith, magnanimity is the same as well-founded or noble pride. In light of this, it appears that good manners compel Hume to ordinarily conceal his magnanimity, or his greatness of soul, from those around him..$^{4}$ Smith, in his "Letter to Strahan" seems to congratulate Hume for this, writing, "He never affected to make any parade of his magnanimity" (EMPL xlvi). But provided Hume typically concealed his magnanimity, how can Smith successfully depict it in his "Letter to Strahan"?

Hume himself qualifies his claim about good manners. First he writes that, "it is only among intimate friends or people of very manly behaviour, that one is allowed to do himself justice" (EPM 8.9/SBN 264). Later he writes that good manners still allow a person's pride to "openly display itself, in its full extent, when one lies under calumny or oppression of any kind" (EPM 8.Io/SBN 265). He gives, as an example, Socrates's "contumacy" when he is brought to trial and condemned to death (EPM 8.Io/SBN 265). Conditions can arise in which a person can, without impropriety, reveal his magnanimity.

Smith, in his own discussions of magnanimity in TMS, adds another such condition, namely the short time prior to a person's own imminent death. He writes:

The man who ... upon the approach of death, preserves his tranquility unaltered, and suffers no word, no gesture to escape him which does not perfectly accord with the feelings of the most indifferent spectator, necessarily commands a high degree of admiration. (TMS VI.iii. 5,238 )

This corresponds entirely with his assertion, much earlier in TMS:

Magnanimity amidst great distress appears always so divinely graceful. His behaviour is genteel and agreeable who can maintain his cheerfulness

4I. This "concealed" magnanimity is a major concern of Benardete's work, but his discussion of it is very different from my own (2013:24-29). 
amidst a number of frivolous disasters. But he appears to be more than mortal who can support in the same manner the most dreadful calamities. (TMS I.iii.I.I3, 47-48)

According to Smith, tranquility and moderation in distress and calamity is a clear sign of magnanimity and greatness of soul. And, he suggests, one's foreseen death is the worst kind calamity, "death . . . is the king of terrors" (TMS VI.iii.7, 239), and maintaining composure near one's death proves the greatest magnanimity: "The man who has conquered the fear of death, is not likely to lose his presence of mind at the approach of any other natural evil" (TMS VI.iii.7, 239).42 One's foreseen death provides him an opportunity to reveal his magnanimity without impropriety or bad manners. A person need not boast to reveal it; he need only continue to maintain a virtuous, cheerful and moderate disposition. Further, the opportunity that a foreseen death provides, in revealing magnanimity, is unique. According to Smith, and echoing a sentiment expressed by the ancient Stoics, ${ }^{43}$ even Socrates's magnanimity might not have been revealed, if he had not had this opportunity: "Had the enemies of Socrates suffered him to die quietly in his bed, the glory even of that great philosopher might possibly never have acquired that dazzling splendor in which it has been beheld in all succeeding generations" (TMS VI.iii.5, 238).

So, too, earlier in his work, Smith writes of Socrates's behavior after he drinks his hemlock. He writes that Socrates recognizes his opportunity to display magnanimity by expressing "the gayest and most cheerful tranquility" (TMS I.iii.I.I4, 48). According to Smith, Socrates "fixes his thoughts . . . upon . . . the applause and admiration which he is about to deserve by the heroic magnanimity of his behaviour" (I.iii.I.I 4, 49).

In his "Letter to Strahan," Smith seizes upon the opportunity to write about Hume's own foreseen death, in order to reveal Hume's own greatness and magnanimity. This is why Smith frequently stresses both Hume's "cheerfulness" and Hume's awareness that he is near death. Smith emphasizes that Hume could remain cheerful and tranquil, despite his weakness and discomfort. Smith seems, implicitly, to compare to Socrates, describing Hume's cheerful discussions with friends as his death approaches. By connecting Hume and Socrates, the great-souled philosopher, Smith even more emphatically emphasizes Hume's own magnanimity.

42. Schliesser acknowledges this point, though in a different context (2003:338).

43. While Smith disagrees with the Stoics on numerous points, he does draw from their writings on others. Here, for instance, his claim about Socrates is similar to one made by Seneca, who, in Letter I3, writes: "Well, what if [the worst] does happen? Let us see who wins! Perhaps it happens for my best interests; it may be that such a death will shed credit upon my life. Socrates was ennobled by the hemlock draught [emphasis added]. Wrench from Cato's hand the sword, the vindicator of liberty, and you deprive him of the greatest share of his glory" (Seneca 8I, 83). Eric Schliesser writes briefly about Seneca's thoughts on philosophers and popular acclaim (revealed magnanimity) in his blog (20I4). 
It is no wonder that, as Laurence Berns recognizes, the end of Smith's "Letter to Strahan" echoes the very end of Plato's Phaedo (Berns I 994: 90, n. 22), ${ }^{44}$ mentioning Hume's death and describing him "as approaching ... the idea of a perfectly wise and virtuous man” (EMPL xlix).

As Berns also recognizes, to depict Hume as the perfect standard of virtue, Smith must depict Hume like Socrates-not only just and beneficent, but magnanimous as well (I994: 89). Smith seizes the singular opportunity of Hume's final days, and foreseen death, to make his case that Hume has virtues both great and soft. After all, Smith suggests that an individual of perfect virtue must have, not only "the soft, the amiable, and the gentle virtues" such as humanity, but also the "great" and "respectable" virtue of magnanimity as well. I conclude this essay with a final, beautiful quote:

The man of the most perfect virtue, the man whom we naturally love and revere the most, is he who joins, to the most perfect command of his own original and selfish feelings, the most exquisite sensibility both to the original and sympathetic feelings of others. The man who, to all the soft, the amiable, and the gentle virtues, joins all the great, the awful, and the respectable, must surely be the natural and proper object of our highest love and admiration. (TMS III.3.35, I 52; see also I.i.5.I)

\section{Acknowledgments}

Many thanks to Ryan Patrick Hanley and José A. Benardete for invaluable conversations and feedback. Many thanks, also, to the anonymous referees for their helpful comments on earlier drafts of this paper.

\section{Abbreviations}

EHU =David Hume (I999). An Enquiry Concerning Human Understanding. Ed. Tom L. Beauchamp. Oxford University Press. Cited by section and paragraph, and including page references to the third Selby-Bigge edition, as revised by P.H. Nidditch (Clarendon Press, I975), e.g., EHU 5.I/SBN 40.

EN = Aristotle (2002). Nicomachean Ethics. Trans. Christopher Rowe. Oxford University Press. Cited by approx. line numbers, and page number, e.g., EN I I 24a I 4-I 8, I 49.

44. Hanley and Schliesser both pick up on this point, and highlight it as well (Hanley 2002a: 682-683; Schliesser 2003: 33I). 
$\mathrm{EPM}=$ David Hume (1998). An Enquiry Concerning the Principles of Morals. Ed. Tom L. Beauchamp. Oxford University Press. Cited by section, part (when applicable), paragraph, and including page references to the third Selby-Bigge edition, as revised by P. H. Nidditch (Clarendon Press, I975), e.g., EPM 7.4/ SBN 252.

EMPL = David Hume (1985). Essays Moral, Political, and Literary. Revised edition. Ed. Eugene F. Miller. Liberty Fund.

History = David Hume (1983). The History of England, Vol. 6. LibertyClassics.

Honour: David Hume (2OI2). An Historical Essay on Chivalry ad Modern Honour. Included as an Appendix to John P. Wright, Hume on the Origin of 'Modern Honour': A Study in Hume's Philosophical Development. In Ruth Savage (Ed.), Philosophy and Religion in Enlightenment Britain: New Case Studies (204-209). Oxford University Press. Cited by paragraph (II) numbers, e.g., Honour III I.

$\mathrm{L}=$ Thomas Hobbes (I996). Leviathan . Revised Student Edition. Ed. Richard Tuck. Cambridge University Press. Cited by part, chapter, and page numbers that follow the pagination of the first ( $165 \mathrm{I}$ ) edition, as indicated in the margins of this modern edition, e.g., L I.I4, 70.

Letters = David Hume (1932). The Letters of David Hume, Vol I. Ed. J. Y. T. Greig. Oxford University Press. Cited by Letter and page number, e.g., Letters No. I, IO.

Seneca = Lucius Annaeus Seneca (1967). Seneca Ad Lucilium Epistulae Morales, Vol. I. Trans. Richard M. Gummere. Harvard University Press.

ST $=$ S. Thomas Aquinas (I 966). St Thomas Aquinas, Summa Theologicae, Volume 42, Courage. Trans. Anthony Ross O.P. and P. G. Walsh. Blackfriars in conjunction with McGraw-Hill Book Company and Eyre \& Spottiswoode. Cited by part, question, article, adversus, and page number, e.g., ST II-II, Q. I 29, Art. 4, ad. 3 , II 3 .

Sublime = Longinus (I99I). On Great Writing (On The Sublime). Trans. G. M. A. Grube. Hackett.

$\mathrm{T}=$ David Hume (2000). A Treatise of Human Nature. Eds. David Fate Norton and Mary J. Norton. Oxford University Press. Cited by book, part, section, and paragraph number, and including page references to the second Selby-Bigge edition, as revised by P.H. Nidditch (Clarendon Press, I978), e.g., T 3.3.3.3/ SBN 604.

TD = Cicero (I927). Tusculan Disputations. Trans. J. E. King. William Heinemann. Cited by book, paragraph, and page number, e.g., TD II.xiii, I49.

TMS = Adam Smith (r974). The Theory of Moral Sentiments. Eds. D. D. Raphael and A. L. Macfie. Clarendon Press. Cited by part, section, chapter (when applicable), paragraph, and page number, e.g., TMS VII.ii.4.2, 306. 


\section{References}

Ainslie, Donald C. (2006). Hume's 'Life' and the Virtues of the Dying. In Thomas Mathien and D. G. Wright (Eds.), Autobiography as Philosophy: The Philosophical Uses of Self Presentation. Routledge. Kindle Edition.

Ardall, Pall S. (I 989). Hume and Davidson on Pride. Hume Studies, I 5(2), 387-394. http:// dx.doi.org/10.1353/hms.2011.0403

Baier, Annette. (I978). Hume's Analysis of Pride. The Journal of Philosophy, 75(I), 27-40. http://dx.doi.org/10.2307/2025832

Baier, Annette C. (2006). Hume's Deathbed Reading: A Tale of Three Letters. Hume Studies, 32(2), 347-356.

Barnes, Jonathan (1975). Aristotle's Posterior Analytics. Clarendon Press.

Benardete, José A. (2013). Greatness of Soul in Hume, Aristotle, and Hobbes as Shadowed by Milton's Satan. Cambridge Scholars Publishing.

Berns, Laurence (1994). Aristotle and Adam Smith on Justice: Cooperation Between Ancients and Moderns?. Review of Metaphysics, 48(I), 7 I-90.

Brand, Walter (2010). Hume on the Value of Pride. Journal of Value Inquiry, 44(3): 34 I350. http://dx.doi.org/10.1007/s10790-010-9228-y

Davidson, Donald (1976). Hume's Cognitive Theory of Pride. Journal of Philosophy, 73 (4), 744-756. http://dx.doi.org/10.2307/2025635

De Jonge, Casper C. (2012). Dionysius and Longinus on the Sublime: Rhetoric and Religious Language. American Journal of Philology, I33(2), 27I-300. http://dx.doi. org/10.1353/ajp.2012.0016

Fetter, James and Walter Nicgorski (2008). Magnanimity and Statesmanship: The Ciceronian Difference. In Carson Holloway (Ed.), Magnanimity and Statesmanship (29-47). Rowman \& Littlefield Publishers.

Guimãres, Lívia (2008). Skeptical Tranquility and Hume's Manner of Death. The Journal of Scottish Philosophy, 6(2), I I 5-I34. http://dx.doi.org/10.3366/E1479665108000171

Hanley, Ryan Patrick (2002a). Hume's Last Lessons: The Civic Education of 'My Own Life'. The Review of Politics, 64(4), 659-685. http://dx.doi.org/10.1017/ S0034670500035919

Hanley, Ryan Patrick (2002b). Aristotle on the Greatness of Greatness of Soul. History of Political Thought, 23(I): I-20.

Hanley, Ryan Patrick (2007). David Hume and the Modern Problem of Honor. The Modern Schoolman, 84(4), 295-3 I 2. http://dx.doi.org/10.5840/schoolman200784418

Hanley, Ryan Patrick (2009). Adam Smith and the Character of Virtue. Cambridge University Press. http://dx.doi.org/10.1017/CBO9780511581212

Homer (I970). The Odyssey. In Samuel Butler (Trans.), The Iliad and The Odyssey (3927I4). Barnes \& Noble, Inc.

Howland, Jacob (2002). Aristotle's Great-Souled Man. The Review of Politics, 64(I), 2756. http://dx.doi.org/10.1017/S0034670500031600

Kaufmann, Walter (I960). From Shakespeare to Existentialism. Anchor Books.

Martin, Marie A. (I992). Hume on Human Excellence. Hume Studies, I 8(2), 383-399. http://dx.doi.org/10.1353/hms.2011.0464

Mossner, Ernest Campbell (I950). Philosophy and Biography: The Case of David Hume. The Philosophical Review, 59(2), I 84-201. http://dx.doi.org/10.2307/2181501

Schiesaro, Alessandro (r997). Passion, Reason, and Knowledge in Seneca's Tragedies. In 
Susanna Morton Braund and Christopher Gill (Eds.), The Passions in Roman Thought and Literature (89-III). Cambridge University Press.

Schliesser, Eric (2003). The Obituary of a Vain Philosopher: Adam Smith's Reflections on Hume's Life. Hume Studies, 29(2), 327-362. http://dx.doi.org/10.1086/589534

Schliesser, Eric (2008). Review of The Impartial Spectator: Adam Smith's Moral Philosophy by D. D. Raphael and Adam Smith in Context: A Critical Reassessment of Some Central Components of His Thought by Leonidas Montes. Ethics, I I 8(3), 569-575.

Schliesser, Eric. (2014, March 8). On Unheroic Philosophers [Web log post]. Accessed 8 Mar. 20I3. Retrieved from http://digressionsnimpressions.typepad.com/ digressionsimpressions/2014/03/i-beg-you-to-consider-those-stoics-who-shut-outfrom-public-life-have-withdrawn-into-privacy-for-the-purpose-of-improvi.html.

Solomon, Graham (2000). Hume on 'Greatness of Soul'. Hume Studies, 26(I), I 29-I 42. http://dx.doi.org/10.1353/hms.2011.0176

Strauss, Leo (1963). The Political Philosophy of Hobbes, Its Basis and Its Genesis. Trans. Elsa M. Sinclair. University of Chicago Press.

Taylor, Jacqueline (20I2). Hume on the Dignity of Pride. The Journal of Scottish Philosophy, Io(I), 29-49. http://dx.doi.org/10.3366/jsp.2012.0026

Wright, John P. (20I2). Hume on the Origin of 'Modern Honour': A Study in Hume's Philosophical Development. In Ruth Savage (Ed.), Philosophy and Religion in Enlightenment Britain: New Case Studies (I 87-209). Oxford University Press. 